\title{
SINTESIS PEREKAT TANIN RESORSINOL FORMALDEHIDA DARI EKSTRAK KULIT POHON MANGIUM UNTUK PENINGKATAN KUALITAS BATANG SAWIT ${ }^{1}$ \\ (Synthesis of Tannin Resorcinol Formaldehyde Adhesive from Mangium Bark Extract for Improving Quality of Oil Palm Trunks)
}

\author{
Okti Rachmawati ${ }^{1}$, Purwantiningsih Sugita ${ }^{1} \&$ Adi Santoso $^{2}$ \\ ${ }^{1}$ Jurusan Kimia, Fakultas MIPA IPB \\ Jl. Tanjung Kampus IPB Dramaga, 16680, Telp/Fax. (0251) 8624567, \\ ${ }^{2}$ Pusat Penelitian dan Pengembangan Hasil Hutan \\ Jl. Gunung Batu No. 5 Bogor, 16001, Telp. (0251) 8633378, Fax. (0251) 86333413 \\ e-mail: octi_rachman@yahoo.co.id \\ Diterima 19 Juli 2017, Direvisi 30 November 2017, Disetujui 17 Januari 2018
}

\begin{abstract}
Oil palm trunk is lower in dimensional stability, density, physical, and mechanical properties than other wood species. Efforts to overcome the weakness of the oil palm trunk properties could be conducted through densification with hot pressing and chemical adhesive addition. This paper studies optimum composition of Tannin Resorcinol Formaldebyde (TRF) in its application for improving the quality of oil palm trunk. The tannins were water extracted at $75^{\circ} \mathrm{C}$ and further copolymerized with resorcinol and formaldehyde. TRF was studied through functional group analysis using infrared spectroscopy and cristallinity test using X-ray diffraction. The TRF adhesive was applied through compregnation process. Results showed that reactivity of tannins in bark of Acacia mangium was 65.82\%, the optimum adhesive composition of TRF $(v / v)$ was $=1: 0.05: 0.05$ with solid content of $8.33 \%, 0.09 \%$ free formaldehyde, and the degree of crystallinity was 10.92\%. Tannin extract has a specific character on the wave number corresponding to the characteristics possessed by the imported tannin acacia standard. The presence of new functional groups and an increase in absorbance intensity of uptake at several wave numbers through infrared spectroscopy analysis on TRF as well as compregnated oil palm trunk indicate the occurrence bonds attributted by ether and methylene bridges to TRF and chemical compound on oil palm trunk. Oil palm trunk after compregnation significantly increased its density by 104.61\%, hardness became 6 fold, and decreased the thickness swell to $85.98 \%$. The oil palm trunk after compregnation also increased in quality from a wood strength class $V$ to a wood strength class III, then, its potential for manufacturing exterior products.
\end{abstract}

Keywords: Tannin Acacia mangium, bark extract, adhesive, compregnation, oil palm trunk

\begin{abstract}
ABSTRAK
Batang sawit memiliki stabilitas dimensi, kerapatan, sifat fisik, dan mekanik lebih rendah daripada jenis kayu lainnya. Upaya mengatasi kelemahan sifat batang sawit dapat dilakukan melalui pemadatan (densifikasi) menggunakan kempa panas dan penambahan bahan kimia atau perekat. Tujuan penelitian ini adalah untuk mendapatkan komposisi optimal tanin resorsinol formaldehida (TRF) dalam aplikasinya sebagai bahan perekat untuk peningkatan kualitas batang sawit. Tanin diekstraksi menggunakan air pada suhu $75^{\circ} \mathrm{C}$ kemudian dikopolimerisasi dengan resorsinol dan formaldehida.
\end{abstract}

${ }^{1}$ Bagian dari Tesis, Jurusan Kimia FMIPA Pascasarjana IPB 
Pencirian TRF dilakukan melalui analisis gugus fungsi menggunakan spektroskopi inframerah, dan kristalinitas menggunakan difraksi sinar X. Perekat TRF kemudian diaplikasikan dalam proses peningkatan kualitas pada batang sawit melalui proses kompregnasi. Hasil penelitian menunjukkan bahwa reaktivitas tanin pada kulit kayu Acacia mangium sebesar 65,82\%, komposisi optimal perekat TRF $(\mathrm{v} / \mathrm{v})=1:$ 0,05: 0,05 dengan kadar padatan sebesar 8,33\%, formaldehida bebas 0,09\%, dan derajat kristalinitas $10,92 \%$. Ekstrak tanin yang dihasilkan memiliki karakter spesifik pada bilangan gelombang yang sesuai dengan ciri yang dimiliki oleh standar tanin akasia impor. Adanya penambahan gugus fungsional baru dan peningkatan intensitas serapan pada beberapa bilangan gelombang melalui analisis spektroskopi inframerah pada TRF dan juga batang sawit hasil kompregnasi, mengindikasikan adanya ikatan yang dihubungkan oleh jembatan eter dan metilena pada TRF serta antara TRF dan komponen kimia pada batang sawit. Batang sawit hasil kompregnasi secara signifikan meningkat kerapatannya sebesar 104,61\%, kekerasan menjadi enam kali lipat, dan penurunan pengembangan tebal sebesar 85,98\%. Batang sawit hasil kompregnasi juga meningkat kualitasnya dari kelas kuat kayu V menjadi kelas kuat kayu III, sehingga berpeluang untuk digunakan dalam pembuatan produk eksterior.

Kata kunci: Tanin Acacia mangium, ekstrak kulit kayu, perekat, kompregnasi, batang kelapa sawit

\section{PENDAHULUAN}

Batang sawit yang dihasilkan dari aktivitas panen akhir biasanya dibiarkan atau dibakar di lokasi perkebunan. Ketersediaan batang kelapa sawit sebagai limbah dari proses panen akhir ini sangat besar, murah dan dapat menjadi sumber bahan baku pengganti kayu yang berkelanjutan untuk berbagai aplikasi jika dapat dimanfaatkan dengan baik. Kerapatan yang rendah, sifat fisik dan mekanis yang rendah (Siregar, 2011) dari kayu batang sawit dibandingkan dengan jenis kayu lainnya menjadi alasan utama pemanfaatannya yang terbatas. Upaya menstabilkan dimensi serta meningkatkan kerapatan dan kekuatan kayu dapat dilakukan melalui pemadatan (densifikasi) dengan menggunakan kempa panas dan penambahan bahan kimia tertentu.

Teknologi modifikasi kayu untuk memperbaiki stabilitas dimensi, sifat fisik, dan mekanis kayu telah dilakukan melalui proses pengempaan kayu pada suhu tinggi terhadap kayu pinus (Laine, Rautkari, Hughes, \& Kutnar, 2013), modifikasi suhu pada proses kempa panas (Candan, Korkut, \& Unsal, 2013), impregnasi terhadap kayu jati dan jabon menggunakan resin vinil akrilat dan polivinil asetat (Basri \& Balfas, 2015) serta teknik kompregnasi menggunakan larutan kitosan 0,5\% terhadap kayu sengon (Nandika, Darmawan, \& Arinana, 2015). Salah satu kekurangan utama dari metode pemadatan kayu melalui pengempaan yaitu pemulihan tebal kayu (springback) yang seringkali terjadi ketika kayu terpadatkan terpapar pada suhu dan kelembapan lingkungan (Candan et al., 2013). Kelemahan tersebut perlu diatasi agar kayu terpadatkan mempunyai nilai guna dan ekonomis yang tinggi. Salah satu peluang untuk mencegah terjadinya springback kayu terpadatkan adalah melakukan impregnasi senyawa kimia ke dalam kayu yang dapat mengisi pori-pori kayu secara permanen dilanjutkan dengan proses pengempaan.

Kompregnasi kayu merupakan gabungan dari proses impregnasi senyawa kimia dan proses pengempaan pada suhu dan tekanan tertentu. Teknik ini potensial untuk meningkatkan stabilitas dimensi dan kekuatan kayu (Basri \& Balfas, 2015; Gabrielli \& Kamke, 2010). Senyawa kimia yang umumnya digunakan sebagai bahan impregnasi kayu merupakan senyawa kimia berbasis formaldehida seperti fenol formaldehida, urea formaldehida dan melamin formaldehida (Gabrielli \& Kamke, 2010) yang memiliki risiko kesehatan akibat emisi formaldehida. Mengingat potensi risiko kesehatan akibat emisi formaldehida yang dihasilkan selama pemakaian produk tersebut, maka pemanfaatan senyawa kimia berbasis formaldehida dalam proses impregnasi kayu harus dikurangi. Oleh karena itu, dibutuhkan alternatif senyawa kimia 
lain yang dapat dipergunakan sebagai bahan impregnasi kayu yang ramah lingkungan. Salah satu upaya alternatif mengatasi hal tersebut adalah menggunakan bahan impregnasi atau perekat dengan campuran bahan alam.

Selama ini perekat yang umum digunakan adalah perekat sintetis urea atau fenol formaldehida yang berasal dari hasil pengolahan minyak bumi dan merupakan sumber daya alam tidak dapat terbaharukan (non-renewable resources). Kelemahan utama dari urea atau fenol formaldehida adalah tidak tahan terhadap cuaca dan air, dan menghasilkan sejumlah besar emisi formaldehida. Salah satu upaya alternatif mengatasi hal tersebut adalah menggantikannya dengan perekat alami yang memiliki keserupaan komponen kimia, yaitu senyawa fenolik dari ekstrak kulit kayu.

Perekat alami dapat dibuat dari limbah kulit kayu karena pada dasarnya kulit kayu mengandung tanin yang dapat diformulasikan sebagai bahan perekat. Penggunaan tanin dapat mereduksi pemakaian resorsinol dari minyak bumi sampai $84 \%$ dan formalin $51 \%$, serta mengurangi ketergantungan bahan perekat impor (Santoso, Malik, \& Hadi, 2015). Selain itu, perekatan dengan menggunakan tanin memberikan hasil produk perekatan berkualitas eksterior dan rendah emisi formaldehida (green technology and green product). Pencampuran tanin dengan formaldehida memberikan hasil perekat yang menyerupai fenol formaldehida dan dapat mengurangi emisi formaldehida (Kim, 2009).

Penelitian terdahulu berkenaan memperoleh produk perekat yang murah dan ramah lingkungan dilakukan dengan mencampurkan tanin dari kulit pohon dengan bahan perekat sintetis (Hoong, Pizzi, Tahir, \& Pasch, 2010; Kim, 2009; Ramires \& Frollini, 2012). Penelitian terkini berupaya untuk mengurangi penggunaan tanin impor dan perekat sintetis serta menurunkan biaya produksi dengan tetap memperhatikan kualitasnya. Upaya tersebut dilakukan dengan menambahkan fortifier atau agen crosslinker seperti fenol dan resorsinol (Santoso et al., 2015; Santoso, Sulastiningsih, Pari, \& Jasni, 2016).

Penelitian ini bertujuan untuk mendapatkan komposisi optimal tanin resorsinol formaldehida (TRF) dalam aplikasinya sebagai perekat pada proses peningkatan kualitas batang sawit yang memiliki stabilitas dimensi, sifat fisik dan mekanis yang tergolong rendah melalui proses kompregnasi.

\section{BAHAN DAN METODE}

\section{A. Bahan dan Alat}

Bahan utama yang digunakan dalam penelitian ini adalah kulit kayu pohon Acacia mangium berumur 7 tahun yang diperoleh dari Parung Panjang Bogor, batang sawit bagian tepi kiri, tengah dan tepi kanan diperoleh dari Balai Penelitian Kelapa, Parungkuda - Jawa Barat, resin fenol formaldehida (PF) komersial, formaldehida $37 \% \mathrm{~b} / \mathrm{v}, \mathrm{NaOH} 40 \% \mathrm{~b} / \mathrm{b}$, resorsinol $50 \%$, dan akuades. Alat-alat yang digunakan adalah peralatan gelas, piknometer, viscometer, oven Memmert, alat pengempa panas Model Becker \& Hullen, alat pengempa dingin, spektrofotometer UV-Vis model Shimadzu seri 1700 PharmaSpec, neraca analitik, penangas air, jangka sorong analog, alat vakum tekan, desikator, FTIR Alpha PlatinumATR Bruker, Difraksi sinar X Rigaku Geigerflex, dan alat uji universal Lohmann-v Tamogrchi essen model UPH-2.

\section{B. Metode Penelitian}

Penelitian terdiri atas enam tahap. Pertama, ekstraksi tanin dari kulit pohon $A$. mangium. Kedua, pencirian ekstrak kulit pohon $A$. mangium. Ketiga, sintesis dan optimasi komposisi perekat TRF. Keempat, pencirian perekat TRF. Kelima, kompregnasi perekat TRF pada batang kelapa sawit dan terakhir adalah pencirian batang sawit hasil kompregnasi.

1. Ekstraksi tanin dari kulit pohon $A$. mangium

Ekstraksi tanin dari kulit pohon $A$. mangium dilakukan dengan cara kulit pohon kering dipotong dengan ukuran $2-3 \mathrm{~cm}$ lalu dihancurkan hingga ukuran partikel $40-60$ mesh. Serbuk kulit pohon kemudian direndam menggunakan air $(1: 3 \mathrm{~b} / \mathrm{v})$ pada suhu $75^{\circ} \mathrm{C}$ selama tiga jam. Cairan ekstrak kulit pohon yang terbentuk disaring lalu dikeringkan menggunakan spray dryer (Hoony et al., 2010). 
2. Pencirian ekstrak kulit pohon $A$. mangium

Pencirian ekstrak meliputi analisis gugus fungsi secara spektroskopi inframerah, pengukuran kadar padatan, bilangan Stiasny, keasaman $(\mathrm{pH})$, kekentalan, dan bobot jenis.

\section{a. Kadar padatan}

Cawan petri kosong ditimbang (W1). Sebanyak 3 gram contoh ekstrak kulit pohon mangium dimasukkan ke dalam cawan tersebut (W2), selanjutnya dikeringkan dalam oven pada suhu $105^{\circ} \mathrm{C}$ selama 3 jam. Cawan didinginkan dalam desikator sampai mencapai suhu ruang, lalu ditimbang (W3). Kadar padatan dihitung dengan rumus pada Persamaan 1.

Kadar padatan $(\%)=\frac{\mathrm{W} 3-\mathrm{W} 1}{\mathrm{~W} 2} \times 100 \% \ldots \ldots$

b. Bilangan stiasny

Contoh ekstrak cair sebanyak $10 \mathrm{~mL}$ ditimbang (W1) dalam piala gelas $150 \mathrm{~mL}$, lalu ditambahkan $1 \mathrm{~mL} \mathrm{HCl} 10 \mathrm{M}$ dan $2 \mathrm{~mL}$ formaldehida $37 \%$. Campuran kemudian dipanaskan dalam penangas air suhu $75^{\circ} \mathrm{C}$ selama 30 menit. Endapan yang terbentuk kemudian disaring dengan kertas saring yang telah ditimbang bobotnya (W2), lalu dikeringkan dalam oven pada suhu $105^{\circ} \mathrm{C}$ dan ditimbang (W3) (Lee \& Lan, 20016). Tingkat kereaktifan tanin dinyatakan dengan bilangan Stiasny dengan membagi bobot endapan terhadap bobot awal contoh (Persamaan 2).

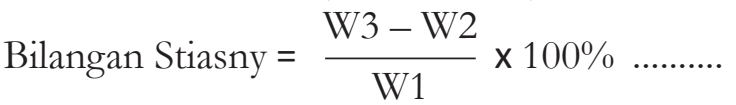

c. Keasaman $(\mathrm{pH})$

Contoh ekstrak cair sebanyak $10 \mathrm{~mL}$ dimasukkan dalam gelas piala kemudian dicelupkan kertas indikator $\mathrm{pH}$ universal, lalu dibaca nilai $\mathrm{pH}$ dengan mencocokkan warna kertas $\mathrm{pH}$ setelah pencelupan dengan warna standar.

\section{d. Kekentalan}

Contoh ekstrak cair dituangkan secukupnya ke dalam bejana viskotester, kemudian diukur kekentalannya dengan alat viskometer dengan satuan poise.

e. Bobot jenis

Piknometer kosong $25 \mathrm{~mL}$ yang bersih dan kering ditimbang (W1). Kemudian diisi air sampai penuh dan ditutup hingga tidak terdapat gelembung udara pada tutup piknometer, lalu ditimbang (W2). Air dalam piknometer dibuang lalu dikeringkan. Selanjutnya piknometer diisi dengan contoh hingga penuh dan ditutup hingga tidak terdapat gelembung udara dalam tutup piknometer, lalu ditimbang kembali (W3). Bobot jenis perekat dihitung menggunakan rumus pada Persamaan 3.

Bobot jenis $=\frac{\mathrm{W} 3-\mathrm{W} 1}{\mathrm{~W} 2-\mathrm{W} 1}$

3. Sintesis dan optimasi komposisi perekat TRF

Ekstrak cair kulit pohon $A$. mangium dicampur dengan $\mathrm{NaOH} 40 \%$ dalam gelas piala, diaduk dan dilakukan pengkondisian $\mathrm{pH}$ hingga 11. Larutan kemudian ditambahkan resorsinol 50\% sedikit demi sedikit dan diaduk dengan tetap dilakukan pengkondisian $\mathrm{pH}$ hingga 11. Ditambahkan larutan formaldehida 37\% sedikit demi sedikit dan diaduk hingga homogen.

Optimasi komposisi tanin resorsinol formaldehida (TRF) dilakukan dengan menghitung kadar padatan pada berbagai variasi komposisi antara tanin dengan resorsinol (TR) dan tanin dengan formaldehida (TF). Setelah didapatkan komposisi optimal untuk resorsinol dan formaldehida, selanjutnya dilakukan variasi komposisi terhadap tanin, resorsinol, dan formaldehida (TRF) (Santoso, Hadi, \& Malik 2012). Komposisi TR, TF, dan TRF sebagaimana tercantum dalam Tabel 1.

\section{Pencirian perekat TRF}

Pencirian perekat TRF meliputi analisis gugus fungsi secara spektroskopi inframerah, derajat kristalinitas menggunakan difraksi sinar X, kadar padatan, keasaman, bobot jenis, kekentalan, dan formaldehida bebas (SNI 4567, 2000).

\section{a. Kadar padatan}

Cawan petri kosong ditimbang (W1). Lalu, $3 \mathrm{~g}$ contoh perekat TRF dimasukkan ke dalam cawan tersebut (W2), dan dikeringkan dalam oven pada suhu $105^{\circ} \mathrm{C}$ selama 3 jam. Cawan didinginkan dalam desikator, lalu ditimbang (W3). Kadar padatan dihitung menggunakan Persamaan 1.

b. Keasaman $(\mathrm{pH})$

Contoh perekat TRF sebanyak $10 \mathrm{~mL}$ dimasukkan dalam gelas piala kemudian dicelupkan kertas indikator $\mathrm{pH}$ universal, lalu 
Tabel 1 Komposisi tanin dengan resorsinol (TR), tanin dengan formaldehida (TF), dan tanin, resorsinol, dan formaldehida (TRF)

Table 1 Composition of tannin and resorcinol (TR), tannin and formaldehyde (TF), and tannin, resorcinol and formaldehyde (TRF)

\begin{tabular}{ccc}
\hline \multicolumn{3}{c}{ Komposisi (Compositions, v/v) } \\
\hline TR & TF & TRF \\
\hline $1: 0,01$ & $1: 0,00$ & $1: 0,05: 0,05$ \\
$1: 0,02$ & $1: 0,05$ & $1: 0,05: 0,10$ \\
$1: 0,03$ & $1: 0,10$ & $1: 0,05: 0,15$ \\
$1: 0,04$ & $1: 0,15$ & $1: 0,05: 0,50$ \\
$1: 0,05$ & $1: 0,20$ & $1: 0,05: 1,00$ \\
$1: 0,10$ & $1: 0,50$ & $1: 0,05: 1,50$ \\
$1: 0,15$ & $1: 0,75$ & \\
$1: 0,20$ & $1: 1,00$ & \\
$1: 0,25$ & $1: 1,25$ & \\
\hline
\end{tabular}

dibaca nilai $\mathrm{pH}$ dengan mencocokan warna kertas $\mathrm{pH}$ setelah pencelupan dengan warna standar.

c. Bobot jenis

Piknometer kosong $25 \mathrm{~mL}$ yang bersih dan kering ditimbang (W1). Kemudian diisi air sampai penuh dan ditutup hingga tidak terdapat gelembung udara pada tutup piknometer, lalu ditimbang (W2). Air dalam piknometer dibuang lalu dikeringkan. Selanjutnya piknometer diisi dengan contoh hingga penuh dan ditutup hingga tidak terdapat gelembung udara dalam tutup piknometer, lalu ditimbang kembali (W3). Bobot jenis perekat dihitung menggunakan Persamaan 3.

d. Kekentalan

Contoh perekat dituangkan secukupnya ke dalam bejana viskotester, kemudian diukur kekentalannya menggunakan alat viskometer dengan satuan poise.

e. Formaldehida bebas

Contoh perekat sebanyak $10 \mathrm{~mL}$ dicampur dengan $10 \mathrm{~mL}$ pereaksi Nash (asetil aseton amonium asetat). Larutan lalu dipanaskan dalam penangas air selama 10 menit pada suhu $40^{\circ} \mathrm{C}$, kemudian didinginkan hingga mencapai suhu ruang. Selanjutnya larutan diukur pada panjang gelombang $418 \mathrm{~nm}$ menggunakan spektrofotometer UV-Vis.

2. Kompregnasi perekat TRF pada kayu batang sawit

Batang sawit tepi kiri, tengah, dan tepi kanan berukuran $5 \mathrm{~cm} \times 3 \mathrm{~cm} \times 2 \mathrm{~cm}$ yang telah diukur panjang, lebar, tebal dan bobotnya disiapkan. Pada setiap sisi batang sawit dilaburkan perekat hingga seluruh permukaannya tertutup merata, lalu didiamkan sampai perekat meresap ke dalam batang sekitar 10 menit. Selanjutnya batang sawit ditimbang lalu dikempa dingin selama 20 menit dengan tekanan $120 \mathrm{~kg} / \mathrm{cm}^{2}$. Selanjutnya dikempa panas pada suhu $120^{\circ} \mathrm{C}$ selama 10 menit dan tekanan 30-40 kg/ $\mathrm{cm}^{2}$. Kemudian diangkat dan dikondisikan dalam suhu ruang selama 24 jam untuk digunakan pada proses pengujian.

3. Pencirian batang sawit hasil kompregnasi

Pencirian meliputi analisis gugus fungsi secara spektroskopi inframerah, derajat kristalinitas menggunakan difraksi sinar $\mathrm{X}$, kerapatan, pengembangan tebal dan kekerasan.

a. Kerapatan

Batang sawit yang telah dilabur, dikempa, dan dibiarkan selama satu hari ditimbang dan diukur 
panjang, tebal, serta lebar menggunakan alat jangka sorong. Kerapatan batang sawit ditentukan mengunakan rumus pada Persamaan 4.

Kerapatan $=\frac{\text { bobot }(\mathrm{g})}{\text { volume }\left(\mathrm{cm}^{3}\right)}$

\section{b. Pengembangan tebal}

Uji pengembangan tebal dibagi menjadi dua, pengembangan tebal setelah direndam dalam air panas selama 4 jam dan pengembangan tebal setelah direndam dalam air dingin selama 24 jam. Batang sawit berukuran $5 \mathrm{~cm} \times 3 \mathrm{~cm} \times 2 \mathrm{~cm}$ yang telah diukur tebal awalnya direndam dalam air dingin selama 24 jam dan dengan air panas suhu $80^{\circ} \mathrm{C}$ selama $4 \mathrm{jam}$. Semua bagian batang sawit harus terendam dengan air. Pengembangan tebal dihitung menggunakan rumus pada Persamaan 5.

Pengembangan tebal $(\%)=\frac{\text { tebal akhir }- \text { tebal awal }}{\text { tebal awal }} \times 100 \% \ldots$ (5)

\section{c. Kekerasan}

Batang sawit sampel diukur kekerasannya menggunakan alat Universal Testing Machine (UTM) dengan meletakkan batang sawit di bawah besi penekan kemudian alat dijalankan. d. Emisi formaldehida

Batang sawit hasil kompregnasi dipotong menjadiukuran $2 \mathrm{~cm} \times 2 \mathrm{~cm} \times 2 \mathrm{~cm}$, lalu diikatpada tutup botol yang berisi $20 \mathrm{~mL}$ akuades sehingga contoh menggantung $(2 \mathrm{~cm}$ di atas permukaan air). Botol lainnya berisi akuades digunakan sebagai blangko. Botol dimasukkan ke dalam oven selama 24 jam pada suhu $40^{\circ} \mathrm{C}$ lalu dikeluarkan dan direndam dengan air. Selanjutnya $10 \mathrm{~mL}$ dari larutan contoh dimasukkan dalam tabung reaksi dan ditambahkan $10 \mathrm{~mL}$ pereaksi Nash (asetil aseton amonium asetat). Larutan tersebut dipanaskan selama 10 menit dalam penangas air dengan suhu $40^{\circ} \mathrm{C}$, kemudian didinginkan hingga suhu ruang. Prosedur yang serupa dilakukan pada larutan blangko. Larutan diukur absorbansinya menggunakan spektrofotometer UV-Vis pada panjang gelombang $418 \mathrm{~nm}$.

\section{HASIL DAN PEMBAHASAN}

\section{A. Ciri Ekstrak Kulit Pohon Mangium}

Cairan ekstrak dari kulit pohon $A$. mangium setelah dikeringkan menghasilkan serbuk

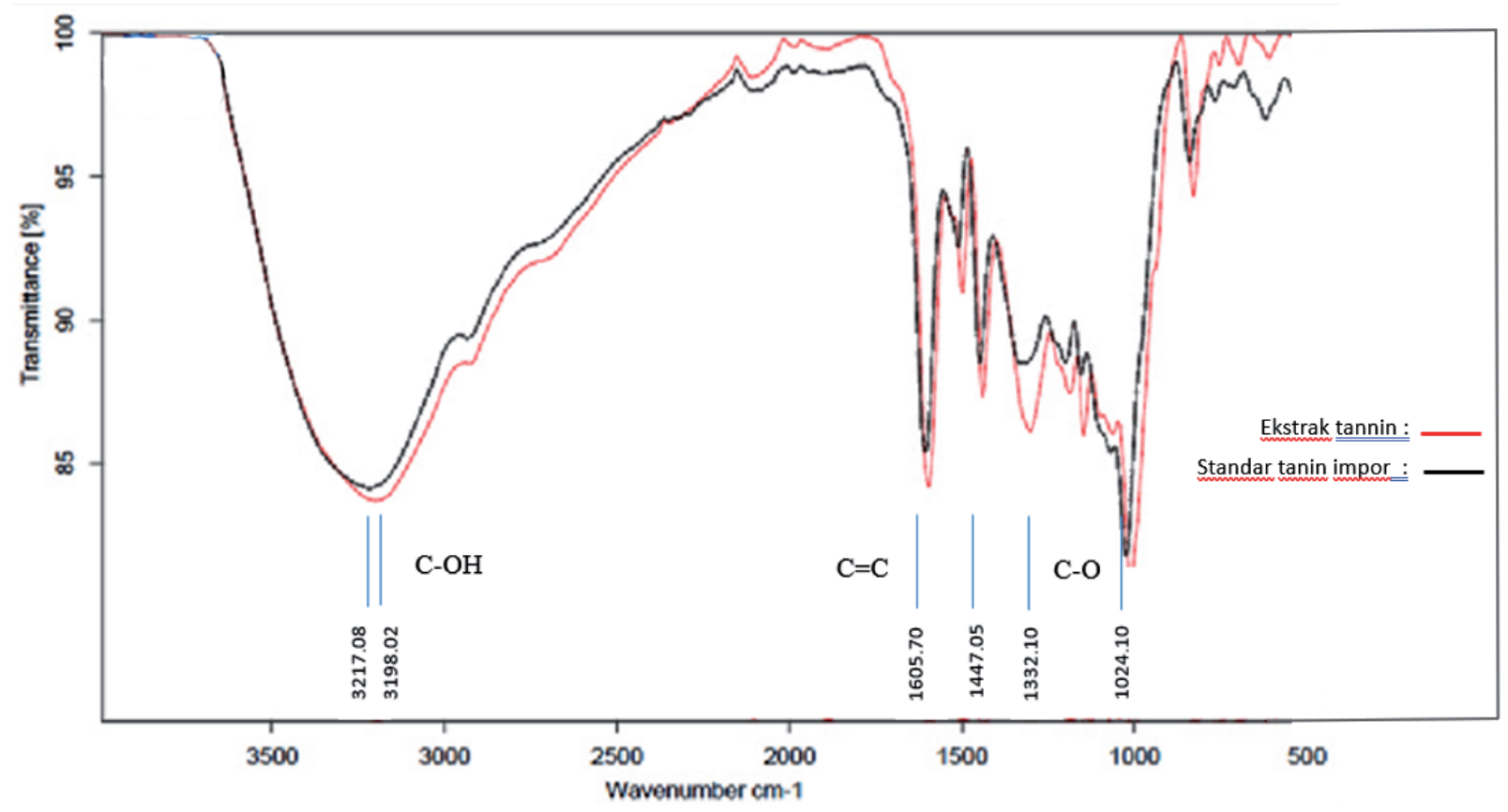

Gambar 1. Spektra inframerah ekstrak tanin dan standar tanin impor Figure 1. Spectra infrared of tannin bark extract and standard of imported tannin 
Tabel 2. Pencirian ekstrak tanin dari kulit pohon Acacia mangium ") Table 2. Characterization of tannin extract from bark of Acacia mangium *)

\begin{tabular}{lc}
\hline \multicolumn{1}{c}{ Sifat (Properties) } & Ekstrak tanin (Tannin extract) \\
\hline Visual (Appearance) & Cairan encer berwarna cokelat kemerahan (Reddish \\
& brown aquous liquid) \\
Keasaman (Acidity, pH) & 4,00 \\
Kekentalan (Viscosity, poise) & 1,04 \\
Kadar padatan (Solid content, \%) & 1,33 \\
Bobot jenis (Specific gravity) & 1,02 \\
Bilangan Stiasny (Stiasny Number, \%) & 65,82 \\
Rendemen ekstrak kering (Yield, \%) & 4,38 \\
\hline
\end{tabular}

Keterangan (Remarks): *) = Rata-rata dari empat kali ulangan (Averages from four replications)

berwarna cokelat kemerahan. Pencirian gugus fungsi terhadap ekstrak tersebut menggunakan spektrofotometer inframerah menunjukkan adanya gugus fungsi spesifik yaitu gugus fenolik dan eter.

Gambar 1 memperlihatkan spektra inframerah dari ekstrak kulit pohon $A$. mangium dan standar tanin akasia impor, keduanya menunjukkan spektra yang serupa yaitu adanya intensitas vibrasi ulur - OH pada bilangan gelombang 3198,02 $\mathrm{cm}^{-1}$ dan 3217,08 $\mathrm{cm}^{-1}$ yang mengindikasikan terwakilinya gugus $\mathrm{OH}$ fenolik dari tanin, vibrasi $\mathrm{C}=\mathrm{C}$ cincin aromatik pada daerah $1400-1600$ $\mathrm{cm}^{-1}$, vibrasi C-O eter siklik pada daerah 1100 $1300 \mathrm{~cm}^{-1}$. Hal ini menunjukkan bahwa ekstrak tanin dari kulit pohon mangium yang diperoleh mengandung senyawa tanin kondensat dengan gugus fungsi spesifik, yaitu fenolik dan eter. Hasil analisis FTIR ini sejalan dengan penelitian yang menyatakan bahwa tanin kondensat memiliki bilangan gelombang spesifik pada daerah $1400-$ $1100 \mathrm{~cm}^{-1}$ dan tidak terdapatnya gugus $\mathrm{C}=\mathrm{O}$ pada daerah 1720-1700 $\mathrm{cm}^{-1}$ (Tondi \& Petutschnigg, 2015).

Pencirian selanjutnya yaitu dengan melakukan pengukuran terhadap ekstrak tanin dari kulit pohon A. mangium disajikan pada Tabel 2. Rendemen ekstrak kering yang diperoleh sebesar 4,38\%. Hasil ini lebih tinggi dari hasil penelitian terdahulu, yaitu dari ekstrak kulit pohon mangium kering dengan pelarut yang sama sebesar 0,85\% (Hindriani, Pradono, \& Santoso, 2005), namun lebih kecil dari penelitian terdahulu sebesar 6,20\% (Hoong, Paridah, Luqman, Koh, \& Loh, 2009), 17,70\% (Mohamad, Zakaria, \& Pizzi,
2010), 23,40\% (Hoong et al., 2010), 16,40\% (Yeoh Beng Hoong, Paridah, Loh, Jalaluddin, \& Chuah, 2011), dan 24,45\% (Feng, Cheng, Yuan, Leitch, \& Xu, 2013). Rendahnya rendemen ini juga terkonfirmasi dengan bobot jenis, kadar padatan, dan kekentalan yang juga cukup rendah dengan nilai masing-masing sebesar 1,02; 1,33\%, dan 1,04 poise. Perbedaan nilai rendemen ini dipengaruhi oleh perbedaan jenis pohon, umur pohon, ukuran partikel sampel, waktu penyimpanan setelah penebangan, serta bahan pelarut dan metode ekstraksi yang digunakan (Feng et al., 2013).

Sifat perekat tergantung pada jumlah kereaktifan tanin dengan formaldehida yang ditunjukkan oleh bilangan Stiasnya. Jumlah bilangan Stiasny sangat penting untuk menghasilkan perekat berkualitas tinggi yaitu minimum sebesar 65,00\% (Feng et al., 2013; Yazaki \& Collins, 1994). Pada Tabel 2 bilangan Stiasny yang diperolah dalam ekstrak cair dari kulit kayu pohon $A$. mangium nilainya $65,82 \%$. Hal ini menunjukkan ekstrak cair yang didapatkan baik untuk digunakan sebagai bahan perekatyang berkualitas. Selain merepresentasikan kadar polifenol (tanin kondensat) yang terdapat dalam ekstrak, bilangan Stiasny juga digunakan untuk menentukan kereaktifan tanin terhadap formaldehida (Hoong et al., 2010; Vieira et al., 2011). Semakin tinggi nilai bilangan Stiasny maka semakin banyak kandungan tanin kondensat dalam ekstrak. Bilangan Stiasny didasarkan pada reaksi tanin dan formaldehida dengan adanya asam hidroklorida untuk menghasilkan produk kondensasi dengan berat molekul tinggi yang tidak larut, yang juga merupakan metode umum 
untuk mengkarakterisasi ekstrak kulit kayu untuk tanin kondensat dan kadar total fenolik (Paridah, Musgrave, \& Ashaari, 2002).

\section{B. Hasil Optimasi Komposisi Tanin Resorsinol Formaldehida}

Penentuan komposisi optimal dilakukan melalui analisis kadar padatan dengan berbagai variasi komposisi antara tanin dan resorsinol (TR) serta tanin dan formaldehida (TF) yang hasilnya disajikan pada Gambar 2 dan Gambar 3.

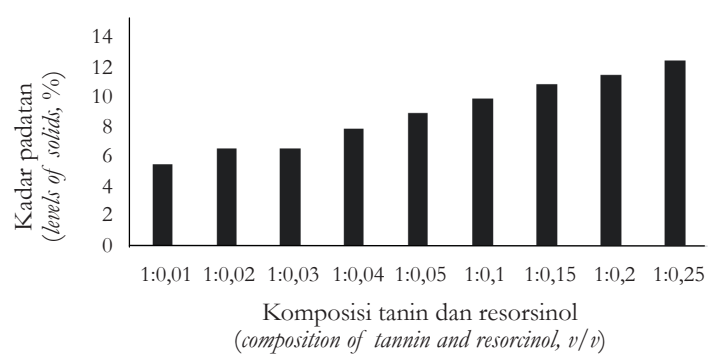

Gambar 2.Pengaruh penambahan resorsinol terhadap kadar padatan

Figure 2. Effect of resorcinol addition on solids content

Gambar 2 memperlihatkan semakin besar penambahan resorsinol akan menyebabkan semakin tinggi pula kadar padatan. Dengan demikian, resorsinol memberikan pengaruh terhadap kadar padatan yang mengindikasikan terbentuknya komponen dengan molekul yang lebih besar.

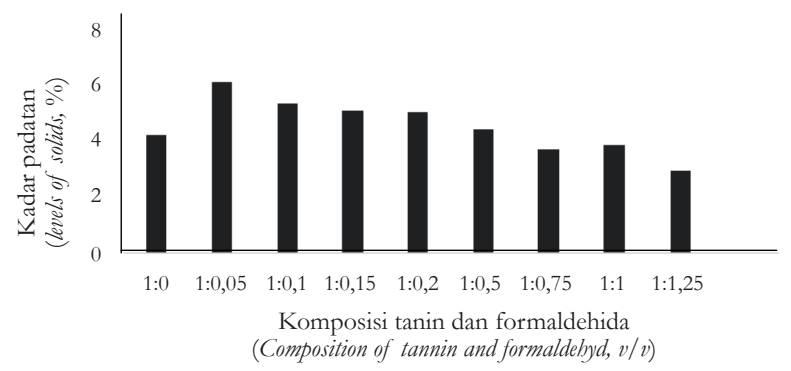

Gambar 3. Pengaruh penambahan formaldehida terhadap kadar padatan

Figure 3. Effect of formaldehyde addition on solids content

Gambar 3 menunjukkan komposisi kadar padatan tertinggi adalah perbandingan TF $(1: 0,05)$ yaitu sebesar $6,20 \%$ dan semakin besar penambahan formaldehida ternyata memberikan pengaruh pada semakin kecilnya kadar padatan yang diperoleh. Hasil ini sejalan dengan penelitian yang menerangkan bahwa peningkatan jumlah aldehida terhadap tanin akan menyebabkan efisiensi reaksi tanin terhadap formaldehida menurun dan mengindikasikan adanya sejumlah aldehida yang tidak ikut bereaksi membentuk produk polimer (Garcia, Glasser, Pizzi, Lacoste, \& Laborie, 2014).

Ikatan rekat maksimum dapat tercapai jika terjadi kontak antara molekul perekat dan komponen kimia pada kayu sehingga terjadi tarikan intermolekul (Santoso et al., 2016). Peningkatan kadar padatan berarti pula peningkatan komponen molekul-molekul perekat yang akan bereaksi dengan komponen kimia kayu pada proses perekatan, sehingga sampai batas tertentu kadar padatan yang tinggi dapat menciptakan keteguhan perekat yang lebih baik, dengan demikian peningkatan kadar padatan resin cenderung meningkatkan kualitas perekatan (Santoso et al., 2016). Maka penentuan komposisi optimum pada penelitian ini didasarkan pada kadar padatan terbesar yang terkandung dalam perekat TRF yang disintesis.

Berdasarkan perbandingan TR dan TF yang diperoleh, kemudian dibuat variasi komposisi antara tanin, resorsinol, dan formaldehida (TRF) yang hasilnya disajikan pada Gambar 4 yang memperlihatkan semakin tinggi perbandingan formaldehida pada TRF menyebabkan penurunan kadar padatan pada produk yang dihasilkan. Kadar padatan tertinggi dihasilkan pada komposisi TRF (1:0.05:0.05) yaitu sebesar $8,33 \%$.

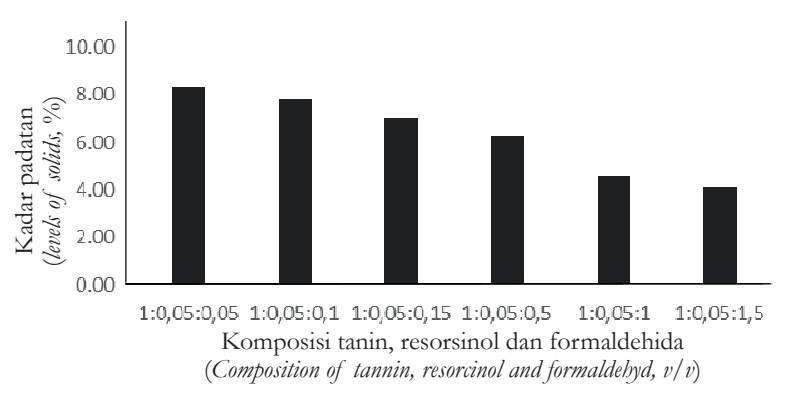

Gambar 4. Pengaruh penambahan resorsinol dan formaldehida terhadap kadar padatan

Figure 4. Effect of resorcinol and formaldehyde addition on solids content 


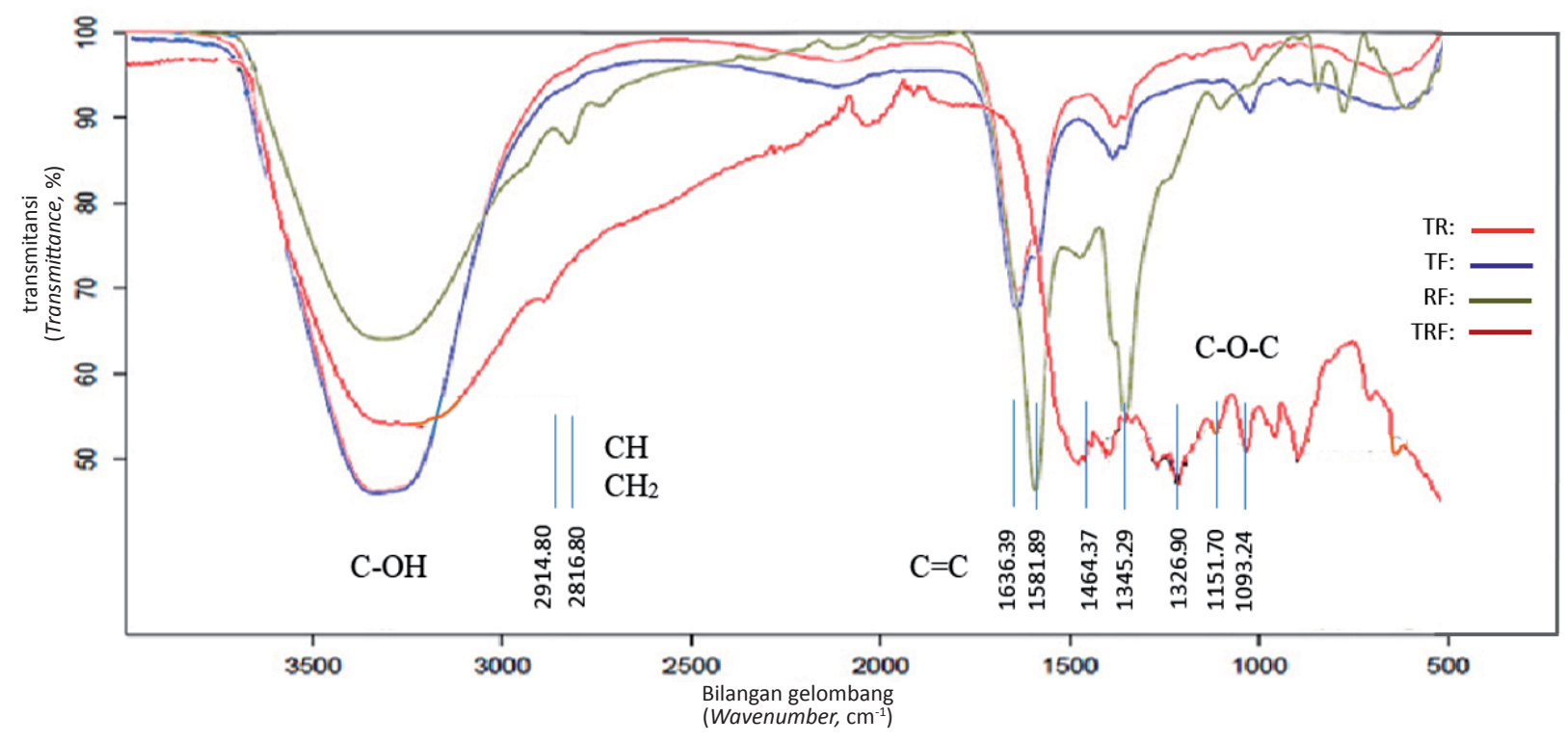

Gambar 5. Spektrainframerah tanin dengan resorsinol(TR), tanin dengan formaldehida(TF), resorsinol dengan formaldehida (RF), dan tanin, resorsinol dan formaldehida (TRF)

Figure 5. Spectra infrared of tannin and resorcinol (TR), tannin and formaldehyde (TF), resorcinol and formaldehyde $(R F)$, and tannin, resorcinol and formaldebyde (TRF)

\section{Pencirian Perekat TRF dan Batang Sawit Hasil Kompregnasi}

Analisis lebih lanjut terhadap sampel menggunakan spektrofotometer inframerah dengan komposisi TR, TF, RF dan TRF ditunjukkan hasilnya pada Gambar 5. Gambar 5 menunjukkan bahwa TR memiliki serapan yang serupa dengan TF, dan jika dibandingkan dengan serapan RF serta TRF terlihat perbedaan, adanya serapan tambahan masing-masing pada bilangan gelombang 2816,8 $\mathrm{cm}^{-1}$ dan $2914,8 \mathrm{~cm}^{-1}$ (vibrasi $-\mathrm{CH}$ dan $-\mathrm{CH}_{2}$ ) yang tidak terdapat pada TR dan TF. Penciri terbentuknya ikatan kimia pada RF dan TRF yaitu adanya serapan pada bilangan gelombang $2816,8 \mathrm{~cm}^{-1}$ dan $1093,24 \mathrm{~cm}^{-1}$ pada RF, sedangkan pada TRF terdapat pada bilangan gelombang $2914,8 \mathrm{~cm}^{-1} ; 1326,9$ dan $1151,7 \mathrm{~cm}^{-1}$. Adanya serapan pada bilangan gelombang 1200-1000 $\mathrm{cm}^{-1}$ menunjukkan adanya vibrasi ulur C-O-C simetrik (Lee \& Lan, 2006) yang mengindikasikan terbentuknya jembatan eter. Adanya serapan di daerah sekitar $2800-2900 \mathrm{~cm}^{-1}$ menunjukkan adanya vibrasi $-\mathrm{CH}$ dan $-\mathrm{CH}_{2}$ (Lisperguer, Saravia, \& Vergara, 2016; Ramires \& Frollini, 2012) yang mengindikasikan terbentuknya jembatan metilena.
Jika spektra TRF tersebut dibandingkan dengan spektra ekstrak tanin terdapat pergeseran serapan pada beberapa bilangan gelombang. Pergeseran serapan dari ekstrak tanin setelah menjadi TRF, terjadi pada bilangan gelombang $3198,02 \mathrm{~cm}^{-1}$ (vibrasi ulur $-\mathrm{OH}$ ) menjadi 3235,3 $\mathrm{cm}^{-1}$, bilangan gelombang $1603,39 \mathrm{~cm}^{-1}$ menjadi $1595,3 \mathrm{~cm}^{-1}$ (vibrasi $\mathrm{C}=\mathrm{C}$ cincin aromatik), bilangan gelombang $1311,96 \mathrm{~cm}^{-1}$ menjadi 1326,90 $\mathrm{cm}^{-1}$ (vibrasi $\mathrm{C}-\mathrm{O}$ cincin aromatik; vibrasi $\mathrm{C}-\mathrm{C}$ ) dan bilangan gelombang 1072,11 $\mathrm{cm}^{-1}$ dan 1021,89 $\mathrm{cm}^{-1}$ menjadi $1021,3 \mathrm{~cm}^{-1}$ (vibrasi ulur $\mathrm{C}-\mathrm{O}$ ).

Pergeseran-pergeseran serapan yang dikemukakan dari spektra ekstrak tanin jika dibandingkan dengan spektra TRF mengindikasikan telah terjadi reaksi antara tanin, resorsinol, dan formaldehida membentuk TRF. Hal ini diperkuat dengan hilangnya serapan pada bilangan gelombang 765,88 $\mathrm{cm}^{-1} ; 709,05 \mathrm{~cm}^{-1}$; $622,33 \mathrm{~cm}^{-1}$ dan $535,14 \mathrm{~cm}^{-1}$ yang merupakan daerah sidik jari yang khas (vibrasi tekuk $\mathrm{C}-\mathrm{H}$ ) untuk formaldehida dan resorsinol. Karakteristik lebih lanjut melalui spektroskopi inframerah untuk mengetahui dugaan adanya ikatan yang terbentuk antara perekat TRF dan komponen 


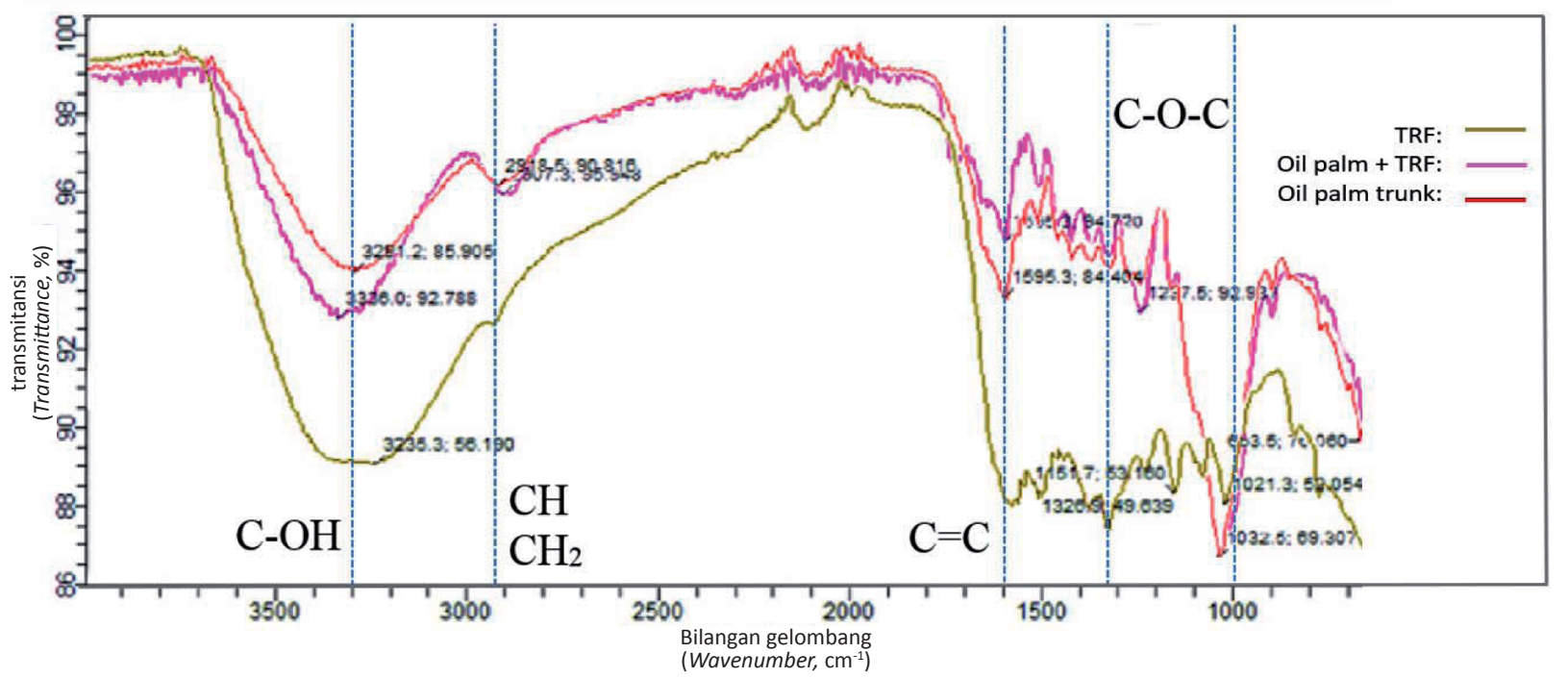

Gambar 6. Spektra inframerah TRF, batang sawit + TRF dan batang sawit Figure 6. Spectra infrared of TRF, oil palm trunk $+T R F$, and oil palm trunk

kimia pada batang sawit dapat ditunjukkan pada Gambar 6.

Gambar 6 memperlihatkan adanya pergeseran serapan pada bilangan gelombang $3235,3 \mathrm{~cm}^{-1}$ dan 2914,8 $\mathrm{cm}^{-1}$ menjadi memiliki bilangan gelombang $3336 \mathrm{~cm}^{-1}$ dan 2907,3 $\mathrm{cm}^{-1}$ setelah ditambahkan TRF pada batang sawit. Selain itu terjadi pula peningkatan serapan yaitu pada serapan vibrasi ulur $-\mathrm{OH}$ sebesar 36,60\%; vibrasi $-\mathrm{CH}$ dan $-\mathrm{CH}_{2}$ sebesar $4,46 \%$; vibrasi $\mathrm{C}=\mathrm{C}$ cincin aromatik sebesar $7 \%$; vibrasi ulur $\mathrm{C}-\mathrm{O}$ cincin aromatik dan vibrasi $\mathrm{C}-\mathrm{C}$ sebesar $43,3 \%$ serta vibrasi ulur $\mathrm{C}-\mathrm{O}$ sebesar $34,57 \%$.

Spektra inframerah batang sawit hasil kompregnasi, jika dibandingkan dengan spektra batang sawit (kontrol) menunjukkan nilai intensitas serapan yang lebih tinggi. Peningkatan tersebut terjadi pada vibrasi ulur $\mathrm{OH}$ sebesar $6,88 \%$, vibrasi ulur $-\mathrm{CH}$ dan $-\mathrm{CH}_{2}$ sebesar $5,09 \%$; vibrasi regangan cincin $\mathrm{C}=\mathrm{C}$ aromatik sebesar 10,32\%, dan vibrasi ulur $\mathrm{C}-\mathrm{O}$ sebesar 17,31\%. Adanya penambahan intensitas atau gugus fungsi baru yaitu vibrasi $-\mathrm{CH}$ dan $-\mathrm{CH}_{2}$ dan gugus $\mathrm{C}-\mathrm{O}-\mathrm{C}$ simetrik pada spektra TRF serta adanya peningkatan intensitas pada beberapa bilangan gelombang, menunjukkan terjadinya ikatan antara komponen penyusun dalam perekat yang dihubungkan oleh jembatan eter dan metilena.

Pencirian perekat TRF selanjutnya yaitu analisis kuantitatif yang hasilnya tercantum pada Tabel
3 yang memperlihatkan telah terjadi perubahan sifat fisik dari seluruh parameter yang diukur. Hal ini ditunjukkan dengan perubahan warna larutan, peningkatan keasaman $(\mathrm{pH})$, kekentalan, kadar padatan, dan bobot jenis dari produk TRF yang dihasilkan jika dibandingkan dengan sifat pada ekstrak kulit pohon $A$. mangium.

Perbandingan dengan perekat fenol formaldehida komersial menurut SNI 4567 (2000) menunjukkan hanya parameter kadar padatan yang tidak sesuai dengan standar tersebut. Hal ini terjadi karena ekstrak tanin yang digunakan memang memiliki kadar padatan dan rendemen ekstrak yang rendah. Nilai formaldehida bebas menunjukkan hasil lebih kecil dari standar yang disyaratkan, sehingga produk yang dihasilkan relatif ramah lingkungan.

Identifikasi lebih lanjut menggunakan difraksi sinar X (Tabel 4) menunjukkan bahwa kayu batang sawit yang dilabur perekat TRF memiliki nilai kristalinitas yang lebih tinggi dibandingkan TRF namun lebih rendah dari kayu batang sawit. Hal ini menunjukkan bahwa TRF mampu membentuk kayu batang sawit yang keras namun tidak regas sehingga kayu batang sawit akan lebih mudah dibentuk untuk pembuatan produk kayu lainnya.

Derajat kristalinitas yang tinggi memiliki kekuatan dan kekakuan yang lebih tinggi dan mengindikasikan struktur polimer tersebut didominasi oleh rantai-rantai dengan keteraturan 
Tabel 3. Karakterisasi kopolimer TRF ${ }^{*}$

Table 3. Characterization of TRF copolymer ${ }^{*}$

\begin{tabular}{lcc}
\hline \multicolumn{1}{c}{ Sifat (Properties) } & $\begin{array}{c}\text { Kopolimer TRF } \\
\text { (TRF copolymer) }\end{array}$ & $\begin{array}{c}\text { Fenol formaldehida } \\
\text { (Phenol formaldebyde) }\end{array}$ \\
\hline Visual (Appearance) & $\begin{array}{c}\text { Cairan kental berwarna hitam } \\
\text { kecokelatan (Black brownish } \\
\text { viscous liquid) }\end{array}$ & $\begin{array}{c}\text { Cairan berwarna merah } \\
\text { kehitaman } \\
\text { (Red blackish liquid) }\end{array}$ \\
Keasaman (Acidity, pH) & 10,00 & $10-13$ \\
Kekentalan (Viscosity, poise) & 2,65 & $1,3-3,0$ \\
Kadar padatan (Solid content, \%) & 8,33 & $40-45 \%$ \\
Bobot jenis (Specific gravity) & 1,17 & $1,165-1,2$ \\
Formaldehida bebas (Free formaldebyde, $\%)$ & 0,09 & $<1$ \\
\hline
\end{tabular}

Keterangan (Remarks): $*$ ) = rerata dari 4 kali ulangan (Averages from 4 replications)

Tabel 4. Nilai derajat kristalinitas melalui analisis difraksi sinar $\mathbf{X}$ Table 4. Degree of crystallinity through $X$ ray diffraction analysis

\begin{tabular}{lc}
\hline Bahan (Materials) & Derajat kristalinitas (Degree of crystallinity, \%) \\
\hline Perekat TRF (TRF Adhesive) & 10,92 \\
Kayu hasil kompregnasi (Compregnated wood) & 17,53 \\
Kontrol (Contro) & 20,83 \\
\hline
\end{tabular}

tinggi serta memiliki gaya antar rantai yang kuat, sehingga rantai atau bagian rantai dapat saling mendekati secara sejajar membentuk daerah kristal.Difraktogram batang sawit tanpa perlakuan (kontrol) menunjukkan nilai kristalinitas sebesar 20,83\%. Nilai ini lebih tinggi dibandingkan kristalinitas batang sawit hasil kompregnasi. Nilai derajat kristalinitas yang tinggi pada batang sawit diduga karena adanya pengaruh lignin dan selulosa dalam kayu batang sawit.

Lignin dan selulosa sering membentuk ikatan yang kuat. Kandungan serat batang sawit merupakan komponen selulosa dan lignin. Serat ini berfungsi sebagai pembangun kekerasan pada setiap kayu. Lignin bertindak sebagai perekat antar serat, sehingga terbentuk kekerasan dan kekuatan pada kayu. Kompregnasi mengakibatkan pelunakan lignin dan selulosa akibat rusaknya ikatan hidrogen antar molekul pada daerah kristalit lignoseluosa yang mengakibatkan berkurangnya nilai kristalinitas dinding sel kayu, maka adanya TRF yang dikompregnasi pada batang sawit menyebabkan berkurangnya daerah kristalin pada lignin dan selulosa sehingga nilai kristalinitas kayu batang sawit hasil kompregnasi lebih rendah dibandingkan dengan batang sawit, dengan kata lain sifat kristalinitas batang sawit menurun setelah berikatan dengan TRF karena gugus hidroksil pada lignin dan selulosa tersubstitusi oleh TRF. Adanya substitusi gugus hidroksil oleh gugus polimer TRF yang lebih besar menambah daerah amorf pada selulosa kayu (Hartono, 2012).

Pencirian selanjutnya, yaitu dilakukan pengukuran terhadap parameter kualitas batang sawit yang dikompregnasi TRF. Hasil pengukuran parameter kualitas batang sawit disajikan pada Tabel 5. Hasil penelitian pada Tabel 5 menunjukkan bahwa rata-rata kerapatan kayu batang sawit setelah kompregnasi mengalami peningkatan masing-masing sebesar 53,64\% dibandingkan tanpa kompregnasi (pelaburan saja), dan 104,61\% dibandingkan dengan batang sawitnya. Hasil ini sejalan dengan penelitian yang menyatakan proses kompregnasi mampu meningkatkan kerapatan sebesar 80,70\% pada kayu Sengon (Nandika et al., 2015).

Kekuatan kayu dipengaruhi oleh kerapatan kayu. Semakin tinggi nilai kerapatan, maka kekuatan kayu meningkat. Kerapatan setiap bagian 
Tabel 5. Nilai rata-rata kualitas batang sawit pada berbagai perlakuan*) Table 5. The average value is of quality of oil palm trunk in various treatments *)

\begin{tabular}{llccc}
\hline Parameter Uji & Bagian \\
(Tested Parameters) & $\begin{array}{l}\text { batang (Part } \\
\text { of stem) }\end{array}$ & $\begin{array}{c}\text { Kontrol } \\
\text { (Controls) }\end{array}$ & $\begin{array}{c}\text { Pelaburan } \\
\text { (Resurfacing) }\end{array}$ & $\begin{array}{c}\text { Kompregnasi } \\
\text { (Compregnation) }\end{array}$ \\
\hline Kerapatan (Density, g/cm $\left.{ }^{3}\right)$ & Tepi kiri & $0,345^{\mathrm{a}}$ & $0,352^{\mathrm{a}}$ & $0,562^{\mathrm{f}}$ \\
& Tengah & $0,171^{\mathrm{b}}$ & $0,193^{\mathrm{d}}$ & $0,346^{\mathrm{a}}$ \\
& Tepi kanan & $0,212^{\mathrm{c}}$ & $0,432^{\mathrm{e}}$ & $0,527^{\mathrm{g}}$ \\
\hline Pengembangan Tebal (Thickness & Tepi kiri & $98,255^{\mathrm{a}}$ & $72,415^{\mathrm{d}}$ & $17,200^{\mathrm{f}}$ \\
& Tengah & $102,380^{\mathrm{b}}$ & $92,455^{\mathrm{e}}$ & $14,330^{\mathrm{fg}}$ \\
& Tepi kanan & $109,193^{\mathrm{c}}$ & $94,503^{\mathrm{e}}$ & $11,520^{\mathrm{g}}$ \\
\hline Kekerasan $\left(\right.$ Hardness, $\left.\mathrm{kg} / \mathrm{cm}^{2}\right)$ & Tepi kiri & $74,000^{\mathrm{a}}$ & $164,750^{\mathrm{c}}$ & $254,750^{\mathrm{c}}$ \\
& Tengah & $24,750^{\mathrm{b}}$ & $75,500^{\mathrm{a}}$ & $85,250^{\mathrm{a}}$ \\
& Tepi kanan & $34,000^{\mathrm{b}}$ & $224,500^{\mathrm{d}}$ & $488,750^{\mathrm{f}}$ \\
\hline
\end{tabular}

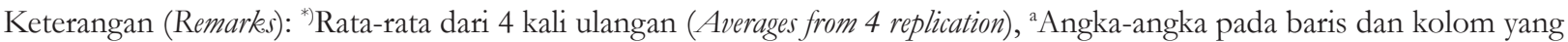
sama yang diikuti oleh huruf yang sama tidak berbeda nyata pada taraf uji $5 \%$ (Values at the same row and column followed by the same letter means not significant different at level of significance 5\%)

yang diamati mengalami peningkatan setelah diberi perlakuan kompregnasi. Nilai rata-rata sebelum perlakuan dari bagian ujung tengah dan tepi berkisar $0,171-0,345 \mathrm{~g} / \mathrm{cm}^{3}$, yang menurut SNI 3257 (1994) tentang mutu dan ukuran kayu bangunan tergolong dalam kelas kayu $\mathrm{V}$ (nilai kerapatan $<0,3 \mathrm{~g} / \mathrm{cm}^{3}$ ). Setelah perlakuan kompregnasi, kerapatan batang sawit berkisar $0,346-0,562 \mathrm{~g} / \mathrm{cm}^{3}$ atau mengalami peningkatan sebesar $62,90-148,58 \%$. Nilai kerapatan batang sawit yang diperoleh tergolong kelas kuat kayu III (nilai kerapatan 0,4-0,6 g/ $\mathrm{cm}^{3}$ ). Hal ini sejalan dengan penelitian yang menyatakan bahwa proses impregnasi dengan stirena mampu meningkatkan kelas kuat kayu menjadi golongan III (Siregar, 2011). Berdasarkan data tersebut nampak bahwa penggunaan TRF dan proses kompregnasi pada batang sawit mampu meningkatkan kelas kekuatan kayu batang sawit. Proses kompregnasi dengan perekat formaldehida mampu meningkatkan stabilitas dimensi kayu dengan semakin meningkatnya kerapatan (Fukuta et al., 2011; Gabrielli \& Kamke, 2010).

Kayu batang sawit yang telah mengalami kompregnasi menunjukkan nilai pengembangan tebal lebih rendah dibandingkan dengan batang sawit kontrol dan hasil pelaburan saja. Rata-rata pengembangan tebal pada kayu batang sawit hasil pengujian memenuhi SNI 4567 (2000) yang mensyaratkan nilai pengembangan tebal sebesar $25 \%$ dari tebal semula. Proses kompregnasi telah menurunkan pengembangan tebal batang kelapa sawit rata-rata sebesar $85,98 \%$.

Nilai kekerasan setelah proses kompregnasi mengalami peningkatan dibandingkan batang sawit dan pelaburan. Peningkatan kekerasan batang sawit yang dikompregnasi terjadi karena adanya pemampatan struktur sel-sel akibat pengempaan, termasuk menyempitnya lumen (rongga-rongga) atau pori-pori dalam sel batang sawit. Selain pori-pori batang sawit menyempit dan terisi oleh perekat TRF, diduga pula karena adanya molekul-molekul TRF yang membentuk jembatan eter dengan komponen kimia batang sawit sehingga kayu menjadi bertambah berat dan padat. Kompregnasi ini menyebabkan TRF masuk ke dalam struktur batang sawit dan mengisi pori dan jaringan parenkim dasar sehingga meningkatkan stabilitas dimensi dan kekerasan dan mengurangi sifat higroskopisnya. Sifat kekerasan ini dipengaruhi oleh kerapatan. Kayu dengan kerapatan tinggi memiliki kekerasan lebih tinggi dibandingkan kayu yang berkerapatan rendah. Batang sawit dengan nilai kekerasan yang lebih besar menjadi lebih stabil dan tidak mudah rapuh. Nilai rerata kekerasan batang kelapa sawit yang telah mengalami kompregnasi lebih tinggi nilainya sebesar $6 \mathrm{kali}$ (dari $44,25 \mathrm{~kg} / \mathrm{cm}^{2}$ menjadi $276,25 \mathrm{~kg} / \mathrm{cm}^{2}$ ) dibandingkan dengan batang sawit kontrol dan 3,5 kali lebih tinggi (dari 44,25 kg/ $\mathrm{cm}^{2}$ menjadi $154,92 \mathrm{~kg} / \mathrm{cm}^{2}$ ) dibandingkan dengan perlakuan pelaburan saja. Hasil ini sejalan dengan 
penelitian yang menyatakan proses kompregnasi mampu meningkatkan kekerasan sebesar 54,61\% pada kayu sengon (Nandika et al., 2015).

\section{KESIMPULAN DAN SARAN}

\section{A. Kesimpulan}

Tanin Resorsinol Formaldehida (TRF) berhasil disintesis dengan komposisi optimal TRF (1:0,05:0,05). Kompregnasi menggunakan TRF meningkatkan kekerasan, kerapatan dan menurunkan pengembangan tebal kayu batang sawit serta meningkatkan kelas kuat kayu batang sawit dari kelas kuat kayu V menjadi III.

\section{B. Saran}

Batang sawit hasil kompregnasi menggunakan TRF dapat digunakan untuk aplikasi pembuatan produk mebel, furnitur, dan pengunaan eksterior. Pengikatan TRF dengan komponen kimia batang sawit yang diduga dihubungkan oleh jembatan eter masih perlu dibuktikan kembali dengan penelitian lanjutan yang lebih spesifik.

\section{UCAPAN TERIMA KASIH}

Penulis menyampaikan terima kasih kepada Kementerian Riset Teknologi dan Pendidikan Tinggi (Ristekdikti) atas fasilitas pendanaan melalui program Beasiswa Pendidikan Pascasarjana Dalam Negeri (BPPDN) Tahun 2015.

\section{DAFTAR PUSTAKA}

Basri, E., \& Balfas, J. (2015). Stabilisasi dimensi kayu jati cepat tumbuh dan jabon dengan perlakuan pemadatan secara kimia. Jurnal Penelitian Hasil Hutan, 33(4), 315-327.

Candan, Z., Korkut, S., \& Unsal, O. (2013). Effect of thermal modification by hot pressing on performance properties of paulownia wood boards. Industrial Crops and Products, 45, 461-464. doi:10.1016/j. indcrop.2012.12.024.

Feng, S., Cheng, S., Yuan, Z., Leitch, M., \& Xu, C. (2013). Valorization of bark for chemicals and materials: A review. Renewable and
Sustainable Energy Reviews, 26, 560-578. doi:10.1016/j.rser.2013.06.024.

Fukuta, S., Watanabe, A., Akahori, Y., Makita, A., Imamura, Y., \& Sasaki, Y. (2011). Bending properties of compressed wood impregnated with phenolic resin through drilled holes. European Journal of Wood and Wood Products, 69(4), 633-639. doi:10.1007/ s00107-010-0506-y.

Gabrielli, C. P., \& Kamke, F. A. (2010). Phenolformaldehyde impregnation of densified wood for improved dimensional stability. Wood Science and Technology, 44(1), 95-104. doi:10.1007/s00226-009-0253-6.

Garcia, D. E., Glasser, W. G., Pizzi, A., Lacoste, C., \& Laborie, M. P. (2014). Polyphenolic resins prepared with maritime pine bark tannin and bulky-aldehydes. Industrial Crops and Products, 62, 84-93. doi:10.1016/j. indcrop.2014.08.010.

Hartono, R. (2012). Peningkatan kualitas batang kelapa sawit bagian dalam dengan metode close system compression dan kompregnasi fenol formaldehida. (Disertasi). Institut Pertanian Bogor, Bogor.

Hindriani, H., Pradono, D., \& Santoso, A. (2005). Sintesis dan pencirian kopolimer tanin fenol formaldeida dari ekstrak kulit pohon mangium untuk perekat papan partikel. Prosiding Simposium Nasional Polimer $V$. Bandung, 22 November 2005.

Hoong, Y.B., Paridah, M.T., Loh, Y.F., Jalaluddin, H., \& Chuah, L.A. (2011). A new source of natural adhesive: Acacia mangium bark extracts co-polymerized with phenolformaldehyde (PF) for bonding mempisang (Annonaceae) veneers. International Journal of Adhesion and Adhesives, 31(3), 164-167. doi:10.1016/j.ijadhadh.2010.12.002.

Hoong, Y.B., Paridah, M.T., Luqman, C.A., Koh, M.P., \& Loh, Y.F. (2009). Fortification of sulfited tannin from the bark of Acacia mangium with phenol-formaldehyde for use as plywood adhesive. Industrial Crops and Products, 30(3), 416-421. doi:10.1016/j. indcrop.2009.07.012. 
Hoong, Y.B., Pizzi, A., Tahir, P., \& Pasch, H. (2010). Characterization of Acacia mangium polyflavonoid tannins by MALDI-TOF mass spectrometry and CP-MAS 13CNMR. European Polymer Journal, 46(6), 1268-1277. doi:10.1016/j.eurpolymj.2010.03.002.

Kim, S. (2009). Environment-friendly adhesives for surface bonding of wood-based flooring using natural tannin to reduce formaldehyde and TVOC emission. Bioresource Technology, 100(2), 744-748. doi:10.1016/j.biortech.2008.06.062.

Laine, K., Rautkari, L., Hughes, M., \& Kutnar, A. (2013). Reducing the set-recovery of surface densified solid Scots pine wood by hydrothermal post-treatment. European Journal of Wood and Wood Products, 71(1), 17-23. doi:10.1007/s00107-012-0647-2.

Lee, W. J., \& Lan, W. C. (2006). Properties of resorcinol-tannin-formaldehydecopolymer resins prepared from the bark extracts of taiwan acacia and china fir. Bioresource Technology, 97(2), 257-264. doi:10.1016/j. biortech.2005.02.009.

Lisperguer, J., Saravia, Y., \& Vergara, E. (2016). Structure and thermal behavior of tannins from Acacia dealbata bark and their reactivity toward formaldehyde. Journal of the Chilean Chemical Society, 61(4), 3188-3190.

Mohamad, S. F., Zakaria, S., \& Pizzi, A. (2010). Pencirian perekat berasas tannin dari kulit pokok Acacia Mangium. International Atomic Energy Agency, 43(56), 1 - 6.

Nandika, D., Darmawan, W., \& Arinana. (2015). Peningkatan kualitas (Paraserianthes falcataria (L) Nielsen ) melalui teknik kompregnasi. Jurnal Teknik Industri Pertanian, 25(2) (August), 125-135.

Paridah, M. T., Musgrave, O. C., \& Ashaari, Z. (2002). Determination of polyphenolic content of bark extracts for wood adhesives. Holzforschung, 56(3), 267-272. doi:10.1515/HF.2002.044.

Ramires,E.C.,\&Frollini,E. (2012). Tannin-phenolic resins: Synthesis, characterization, and application as matrix in biobased composites reinforced with sisal fibers. Composites Part B: Engineering, 43(7), 2851-2860. doi:10.1016/j. compositesb.2012.04.049

Santoso, A., Hadi, Y. S., \& Malik, J. (2012). Tannin resorcinol formaldehyde as potential glue for the manufacture of plybamboo. Journal of Forestry Research, 9(1), 10-15. doi:10.20886/ijfr.2012.9.1.10-15.

Santoso, A., Malik, J., \& Hadi, Y. S. (2015). Teknik pembuatan dan aplikasi perekat resorsinol dari ekstrak limbah kayn merbau. Bogor: Pusat Penelitian dan Pengembangan Hasil Hutan, Kementerian Lingkungan Hidup dan Kehutanan.

Santoso, A., Sulastiningsih, I., Pari, G., \& Jasni. (2016). Pemanfaatan ekstrak kayu merbau untuk perekat produk laminasi bambu. Jurnal Penelitian Hasil Hutan, 34(2), 89-100. doi:10.20886/jphh.2016.34.2.89-100.

Siregar, M. S. (2011). Penguatan sifat mekanik kayu kelapa sawit dengan teknik impregnasi reaktif monomer stirena. Agrium, 16(3), 158-162.

Standar Nasional Indonesia (SNI). (1994). Mutu dan ukuran kayu bangunan. (SNI 3257-1994) Badan Standardisasi Nasional.

Standar Nasional Indonesia (SNI). (2000). Fenol formaldehida cair untuk perekat kayu lapis. (SNI 4567-2000) Badan Standardisasi Nasional.

Tondi, G., \& Petutschnigg, A. (2015). Middle infrared (ATR FT-MIR) characterization of industrial tannin extracts. Industrial Crops and Products, 65, 422-428. doi:10.1016/j. indcrop.2014.11.005.

Vieira, M. C., Lelis, R. C. C., Couto Da Silva, B., De, G., Oliveira, L., \& De Pesquisa, A. (2011). Tannin extraction from the bark of Pinus oocarpa Var. oocarpa with sodium carbonate and sodium bisulfite. Floresta E Ambiente, 18(181), 1-81. doi:10.4322/ floram.2011.017.

Yazaki, Y., \& Collins, P. J. (1994). Wood adhesives based on tannin extracts from barks of some pine and spruce species. Holr. Als Roh- Und Werkstoff, 52(5), 307-310. doi:10.1007/BF02621420. 